\title{
EDITORIAL POLICIES
}

rquivo PDF com versão atualizada das Normas Edito-
riais em português e inglês está sempre disponível para
download no site da Classica ${ }^{1}$.

A PDF file with an updated English version of the Editorial Policies is available in Classica's website.

Classica é um periódico de caráter científico da Sociedade Brasileira de Estudos Clássicos, destinado à divulgação de trabalhos originais e inéditos sobre todos os aspectos das culturas da Antiguidade Clássica e outras culturas do mundo antigo.

Os trabalhos são publicados, preferencialmente, em português, espanhol, inglês, francês ou italiano, nas seguintes modalidades:

1. Artigos. Resultados novos e consolidados de pesquisas - de 3.000 a 8.000 palavras.

2. Artigos de revisão. Revisões críticas de aspectos da Antiguidade, apresentados de modo abrangente e discutidos nas suas implicaçôes - de $6.000 \mathrm{a}$ 10.000 palavras.

3. Notas. Discussão e análise de resultado parcial de pesquisas em andamento, ou de pequenos tópicos de reconhecida relevância - de 1.500 a 3.000 palavras.

4. Instrumentos de pesquisa. Apresentação e discussão de instrumentos de trabalho disponíveis, de natureza documental, material, metodológica, bibliográfica ou de informática - de 3.000 a 6.000 palavras.

5. Ensaios bibliográficos. Análise de conjunto das obras de um mesmo autor ou de suas obras sobre um mesmo tema - de 3.000 a 6.000 palavras.
1. Classica On Line: $<$ http://revista.classica. org.br>. 
6. Resenhas. Análise crítica de obras recentes, publicadas há menos de cinco anos - de 600 a 1.200 palavras.

7. Notícias bibliográficas. Apresentação crítica e sucinta de obras recém publicadas - de 450 a 900 palavras.

8. Traduções: Apresentação de tradução de trechos de obras ou material epigráfico e comentários - de 600 a 2000 palavras

9. Dossiê temático: composto de no mínimo 05 e no máximo 10 artigos inéditos sobre um tema em comum, organizado a convite do Editor.

Todos os trabalhos encaminhados ao Editor, preparados de acordo com as normas editoriais, com as normas da ABNTe compatíveis com a área de atuação da SBEC, são bem vindos. É responsabilidade dos autores obter previamente as autorizações necessárias para a reprodução de imagens, trechos longos de obras publicadas e outros itens protegidos por copyright.

A publicação de trabalhos está condicionada à análise de um ou mais consultores da Classica. Classica utiliza o sistema duplo-cego de revisão, em que autores e consultores não são mutuamente identificados. Os direitos autorais dos trabalhos aceitos para publicação serão regidos de acordo com os do sistema SEER vinculado ao sistema Creative Commons.

Clássica também publica números temáticos, em geral na forma de "suplementos", condicionados a chamadas específicas de trabalhos, ou aos anais de reuniōes, seminários e congressos temáticos promovidos ou co-promovidos pela SBEC, v.g. o Congresso de Estudos Clássicos. 


\section{GUIDELINES FOR AUTHORS}

\section{Focus and Scope}

Classica is scientific and interdisciplinary journal of the Brazilian Society of Classical Studies, for the dissemination of original and unpublished works on all aspects of the cultures of Classical Antiquity and other cultures of the ancient world.

All papers submitted to the Editor, prepared according to the editorial standards, with the ABNT and compatible with the area of operation of SBEC, are welcome. It is the authors' responsibility to obtain prior authorizations necessary for the reproduction of images, extended excerpts of published works and other items protected by copyright.

Classica also publishes thematic issues, generally in the form of "supplements", conditioned on specific calls for papers, or the proceedings of meetings, seminars and thematic conferences promoted or co-promoted by SBEC, e.g. Congress of Classical Studies.

\section{Peer Review Process}

The publication of works is subject to the analysis of one or more consultants of Classica. Classica uses a double-blind review, where authors and consultants are not mutually identified.

The papers are published, preferably in Portuguese, Spanish, English, French or Italian, in the following ways:

1. Articles. Consolidated results and new research 3000-8000 words.

2. Review articles. Critical reviews of aspects of antiquity, presented and discussed comprehensively in its implications - 6000-10000 words.

3. Notes. Discussion and analysis of partial results of research in progress, or small threads of known relevance - 1500-3000 words.

4. Research instruments. Presentation and discussion of available instruments of research, be they documentary, material, methodological, bibliographical or informational - 3000-6000 words. 
5. Bibliographical essays. Analysis of all the works of a single author or his works on the same theme 3000-6000 words.

6. Reviews. Critical analysis of recent works, published within the last five years - 600-1200 words.

7. Bibliographical Notices. Critical presentation and summary of recently published books - 450-900 words.

8. Translations: Translations of excerpts of works or epigraphic materials and commentaries - 6002000 words

9. Thematic Forum: comprised of at least 5 and at most 10 unpublished articles on a common theme, organized at the invitation of the Editor.

The names and email addresses entered in this journal site will be used exclusively for the stated purposes of this journal and is not available for other purposes or to third parties. 